\title{
Imagining Oceans of Law: Oman and East Africa, circa 1910
}

\author{
FAHAD AHMAD BISHARA* \\ E-mail: fabishara@gmail.com
}

This article takes a single moment - a court case that took place in Zanzibar in 1910 - and uses it to explore the legal imaginaries that circulated around the Western Indian Ocean at the height of British imperialism. It stitches together the actions of litigants, the utterances of qadis, and the proclamations of jurists, reading them alongside the silences in the legal material itself to bring to life a world of law, mobility, and imagination. More broadly, it suggests that through the exploration of parallel but never fully intersecting legal encounters in South Arabia and East Africa that emerged from a single moment, historians might use micro-level discourses and actions to make claims about macro-level phenomena.

Keywords: Muscat, Zanzibar, Al-Salimi, law, dates.

How might one begin to imagine (let alone write) a history of law in a place like the Indian Ocean - an expansive space that historians have called an inter-regional arena, a cultural continuum, or, as is the case in this volume, an ocean of law? If historians have cast aside the broad scope of macro-level approaches for their inattentiveness to rich economic, political, and cultural relationships, and similarly eschewed micro-level approaches for being "too engrossed in discourses of the local community and the nation to engage in broader comparisons," how might we imagine the "hundred horizons" that Indian Ocean historians have exhorted us to write about, while still following the fine-grained, often localised or frustratingly abstract discourses on law that form the threads in our tapestry? ${ }^{1}$

This article, at its core, engages with these questions - ones that immediately outstrip its size. It is a small piece, and one that tries to take on a broad topic in a big space. The premise is this: that to write a textured history of law in the Indian Ocean, it might be best to start small — and ultimately, to stay small, even as one (by choice or necessity) steps into the large. As I narrate a story of law in the Indian Ocean - surely one of hundreds of possible stories - I sometimes expand in scale and other times switch viewpoints, all to get at the hundred horizons of law in the Indian Ocean - or at least two or three of those horizons. I start by narrating the details of a particular 
case, tugging on one or two of the loose threads in its fabric and stretching it across the Indian Ocean as I tether it to local, regional, and global actors. The narrative sometimes transcends the case and the actors it involved, but invariably ties itself back down to them, reworking itself into a broader trans-regional fabric-macro processes that are fundamentally bound up in micro-level actors and discourses. The significance of 1910 - an otherwise totally unremarkable year in world history - is in it being thoroughly ensconced in these flows and processes. But enough preamble; a story awaits us.

In 1902, an Arab who had migrated from Oman to Zanzibar, a man named 'Abdullah bin Salam, had approached another Arab - a Zanzibar-based moneylender named Saleh bin Sulaiman - asking him for a loan of Rs 6,000. Saleh later claimed that as security, 'Abdullah had effectively mortgaged property in Oman, from which he was supposed to realise an annual rent of Rs 600 - effectively a form of interest on the loan. ${ }^{2}$ He travelled to Oman that same year to take possession of the property, and left an agent (wakil) there to collect the property's rents and forward them to him in Zanzibar; the principal amount remained unpaid, and 'Abdullah eventually passed away.

In 1910, as 'Abdullah's heirs were sorting through his estate, Saleh lodged a petition in the British magistrate's court in Zanzibar, alleging that 'Abdullah's heirs owed him for the amount he had loaned their father. When asked to produce evidence of the debt, Saleh offered the court a burned document that nobody could read. He had accidentally burned the document, he claimed, when he knocked over an oil lamp, causing the oil to pour out and burn off its most important section. Because Saleh never registered the document at the consulate - when asked why, he claimed that it was because it involved property in Muscat - the court could not find another copy of it to authenticate its veracity. ${ }^{3}$ Seizing on the moment, 'Abdullah's heirs suggested that the document was likely never a mortgage at all, but a power of attorney authorising Saleh to take possession of the Oman property on behalf of their father. The judge agreed: after polling three Muslim judges (qadis) on how to read the instrument and consulting one Islamic legal text directly-Mohammed ibn Yusuf Aṭiyyish's Sharh Al-Nīl, which had become a standard reference in court- he suggested that the document was unlikely to be a sale and was most likely a deed given to Saleh to get possession of the property as an agent of the deceased 'Abdullah bin Salam. 'Abdullah had property in Zanzibar, and if he had borrowed money from Saleh at all — and the judge wasn't altogether convinced that he had — it was unlikely that Saleh would have preferred land in Muscat to land in Zanzibar. ${ }^{4}$

With the court's decision, all would seem to have been settled-except that it hadn't. Seven years after the court handed down its judgement, 'Abdullah's heirs sold the Omani land to another Arab, Saif bin Hamoud, with one condition - that he was to travel to Oman and take it from Saleh bin Sulaiman, whom they claimed had been in "wrongful possession" of the land for nearly a decade! Saleh, it seemed, had circumvented the court's decision by absconding to Muscat and appealing to legal authorities there. Saif left for Muscat to take possession of the land he had bought, 
but "was met with difficulties of a legal nature." He returned to Zanzibar to get fresh certificates from the court, and then travelled again to Muscat, where "local authorities" upheld his claim to the property, but insisted that he pay Saleh. ${ }^{5}$ Frustrated, Saif returned to Zanzibar, where he entered a successful claim against 'Abdullah's heirs to refund the amount he had paid them for the Oman property.

The series of transactions and disputes between 'Abdullah bin Salam's family, Saleh bin Sulaiman, and Saif bin Hamoud highlights the major juridical tensionsbut also transformations - in the Western Indian Ocean at a time of high imperialism. On the face of it, the confusion stemmed from the inability of actors in the courtroom to read a legal instrument whose provenance could not entirely be ascertained - one that had its roots in a series of loans, promises, and movements that dated back more than twenty years. At the same time, however, the case highlights the competing legal authorities that continued to jostle with one another in their attempts to define the document: the British judge and the qadis who weighed in on the disputes, but also the "local authorities" in Oman, who intervened in the matter at several critical junctures. In a sense, the disputes between the three different parties open up the multiple legal worlds that Indian Ocean commercial actors traversed over the course of their lifetimes, but also point to the gaps between those legal worlds - gaps that allowed actors like Saleh bin Sulaiman to retain possession of properties in Oman even though a court in Zanzibar ruled against him, or for the litigants to alternatively claim that the instrument was a sale, a mortgage, or a power of attorney.

But then, in the middle of the legal proceedings, one actor made a surprising - and profoundly revealing - declaration. When asked about whether the court could hear cases relating to wealth in Oman, one of the qadis, Taher bin Abibaker Al-Amawi, responded that it could, and that it was not impeded whether the two litigants were present in its jurisdiction or not. He continued: "In the sharia the qadi's ruling is upheld in any case relating to property that is absent, whether it is in his jurisdiction or another part of the world. We thus hold that this court can hear claims on all things that claims can be heard on, whether they are present in its jurisdiction or absent from it." 6

By suggesting a qadi had jurisdiction over property-related matters anywhere, AlAmawi hearkened back to a world of law in which claims based on legal instruments that were upheld by one qadi would be upheld by every other qadi, whether he was in Zanzibar, Mombasa, Muscat, "or another part of the world." A universal qadi jurisdiction seems surprising given its immediate context - a British court at a time of high imperialism. By the 1890s, as British protectorates were declared around the Western Indian Ocean, a British Indian colonial legal bureaucracy had taken shape along the East African coast and in parts of South Arabia-in many ways, an extension of that in British India itself. Over the course of three decades, British officials in East Africa imported Indian statutes as British and Indian lawyers referenced Indian case law and procedural codes in British courtrooms. ${ }^{7}$ Historians agree that, as in India, the place of the qadi within this quickly-changing juridical landscape was shrinking; while litigants often took marriage-related disputes to a qadi, the 
latter's role had lost much of the independence it had enjoyed in the past, the qadis' voices having been largely drowned out by colonial judges, metropolitan lawyers, and layers of bureaucracy. ${ }^{8}$ Al-Amawi's assertion of a universal qadi jurisdiction is thus surprising, given its context.

But this wasn't all just wishful thinking on Al-Amawi's part. Despite the continued growth of a British Indian legal bureaucracy in East Africa, there still existed a world of contracting regulated by qadis, scribes, jurists, merchants, and planters - a world that animated Al-Amawi's response, even as he wrote it while sitting in an advisory role in a British-headed courtroom. This was a world that existed beyond the boundaries of the British courts, but which always ran alongside them and often intersected with them as legal instruments and capital exchanged hands, and as Muslim legal actors-Al-Amawi, but also many others like him — sought to stake their claims over an increasingly connected world.

To get at the world of qadi jurisdiction that Al-Amawi hinted at in his statement, this article follows the litigants from Zanzibar to Oman and back, and looks into the "local authorities" whose judgements shaped the proceedings of that court case. In its movement, it looks out across the sea from different locales and maps out the multiple, intersecting worlds of law and commerce that stretched out across the Western Indian Ocean, linking Oman to East Africa. Even at the zenith of the British Empire in the region, law, the case makes clear, was not singular and did not move in a single direction: rather, there circulated multiple currents of legal thought and transformation, all of which sought to guide the movement of people, goods, and capital around the Indian Ocean littoral. By unpacking the changing worlds of regional commerce and the multiple claims to an expansive Islamic legal space within it, this article highlights the texture of legal and economic life in the Western Indian Ocean both within and beyond the British courtroom.

\section{Economic Change in Oman and East Africa}

That the different parties to the case were litigating over property in Oman deserves some explanation, particularly since Muscat and Oman have mostly been written out of the commercial transformations that swept the Indian Ocean during the nineteenth century. ${ }^{9}$ Scholars who highlighted the links between Oman and East Africa during the first half of the nineteenth century have tended to either end their narratives with the Canning Award, which split the Omani Empire into two administrations in Muscat and Zanzibar, or assume that Oman receded into the background after Zanzibar's integration into the world economy. ${ }^{10}$ Even those writing on Oman itself have tended to characterise the second half of the nineteenth century as a period of commercial decline. ${ }^{11}$ And there is good reason to highlight East Africa over Oman: during the nineteenth century capital frequently moved from the latter to the former. As a series of commercial booms unfolded along the East African coast, Omanis and other Arabs were investing their capital there-not in Oman. The expansion of the trade in ivory and slaves - and later, cloves - attracted merchants, planters, and 
financiers from around South Arabia and Western India, all of whom looked to profit from the commercial bonanza.

However, at the time Saleh loaned out money to 'Abdullah, his commercial prospects in East Africa were probably looking less attractive than they had in years past. Since the establishment of British protectorates in Zanzibar and what is today Kenya in the 1890s and the development of the Uganda Railway at the turn of the century, East Africa had become oversaturated with international capital, opportunities for Arab merchants had shrunk, and returns on loans to planters and ivory traders were not nearly what they had been in the past. Opportunities to engage in the ivory trade were also diminishing: by the century's close the Belgians had all but secured their hold over the Congo, and the Germans over Tanganyika. ${ }^{12}$ The region was also overrun with English and Indian lawyers and judges, who intervened in commercial contracting at every step of the process, regulating transactions more and more with every year that passed. For a moneylender like Saleh, then, it was a bad time to be doing business in East Africa.

Not all was lost, though; as some doors closed, others opened. At the time 'Abdullah and Saleh first contracted with one another, a commercial boom was unfolding across the sea in Oman. By the end of the nineteenth century, the Omani date trade to London and the United States had grown to unprecedented proportions as British and American merchants and shippers all jockeyed to secure supplies of the fruit. With this commercial transformation in mind-or at least the sense that the value of dates and property in Oman was on the rise-the prospect of loaning out money in Zanzibar against property an ocean away would have seemed like a good idea. By 1885 , Americans were importing nearly 10 million pounds of dates every year. ${ }^{13}$ Between 1899 and 1906, the earliest years for which there are published export figures, Muscat's date exports nearly doubled, from over $\$ 250,000$ to almost $\$ 450,000$, peaking at over $\$ 500,000$ in $1902-3 .{ }^{14}$ The amount of dates exported only grew in the years that followed: by 1913, Muscat exported nearly 30 million pounds of dates, nearly twice that a decade later, and almost three times that amount by 1925. ${ }^{15}$ In the first few decades of the twentieth century, then, the Omani date trade had swelled to truly global proportions.

Perhaps no one could speak more to these changes than the Kachchhi merchant Ratansi Purshottam, who profited directly from the expansion of the Omani date trade. Ratansi first arrived in Muscat in 1857, at the age of fourteen, to work as a clerk at his uncle's shop. He established his own business ten years later, most likely on capital borrowed from his uncle. Over time, he developed a thriving business that dealt in grain, coffee, textiles, and a range of different goods - including dates, which he exported to his own business offices in Karachi and his brother's business in Bombay. ${ }^{16} \mathrm{He}$ was one of a number of Indian merchants around Muscat and the Persian Gulf who engaged in the regional date trade. ${ }^{17}$ His date trading was bound up in his moneylending and general trading activities: he would loan money and goods to middlemen operating in date-growing regions and expect them to forward him dates. 
Ratansi's date business took on new significance when he began doing business with a New York-based firm in 1905. Having dealt in dates for some time, and having an extensive network of middlemen and planters supplying him from the interior, Ratansi was well placed to serve the needs of prospective date traders from abroad. And Ratansi was able to mobilise his network towards his new business venture, taking advantage of the opportunities that the New York-based firm offered him. Over the course of a few years, he shipped out tens of thousands of boxes of Omani dates, drawing on the New York merchant's extensive credit network to finance the orders. Through a network of bankers in London and Bombay, Ratansi and his partners directed global circuits of finance to Muscat and from there to middlemen operating on the coast and interior. ${ }^{18}$ In a way, Ratansi, and other Indian merchants like him, bridged date plantations in Oman to markets in Europe and the United States, mediating between global regimes of trade finance and local regimes of debt and property. These traders forged the international chains that linked Oman to Basra, Karachi, Bombay, and New York. What had once been a regional commodity had become transformed into a global one.

Thus, when the Zanzibari Arab merchants and moneylenders Saleh bin Sulaiman and Saif bin Hamoud jockeyed with one another for the right to 'Abdullah bin Salam's property in Oman, it was in this context - a time in which the growing date trade, made possible by merchants like Ratansi Purshottam, had rendered land more valuable than it had been for decades. Saleh and Saif would have both known of the possibilities that land in Oman could offer, and would have been willing to risk a possible default by 'Abdullah bin Salam — or in Saif's case, the risk of a speculative purchase of land in the hands of a stranger across the sea-for the promise of rewards in the growing global date trade.

At the same time, in pursuing land in Oman, they counted on there being a legal system that would uphold their property rights - one that wouldn't interfere with their relationships with their debtors nor impose limits on their ability to collect rent or, if necessary, foreclose on property. That Saleh was able to hold onto 'Abdullah bin Salam's properties in Oman for more than seven years after the courts in Zanzibar had ruled against him suggested that he knew something that the judges didn't. And the fact that when Saif left Zanzibar for Muscat to take the land from Saleh he "was met with difficulties of a legal nature" indicates that Saleh had played the right cards. And he did: in 'Abdullah bin Salam's date garden, an ocean away, the British court was nowhere to be seen, and commercial actors like Saleh could appeal to a completely different set of authorities to uphold his claims.

\section{Bridging Land and Sea}

From his residence in Al-Qabil, an agricultural village in the northeast of Oman not far from the date plantations of the Batinah, the blind Muslim jurist 'Abdullah bin Humayd Al-Salimi might not have been able to see the globalisation of Oman's date trade, but could feel the pressures it was placing on local date farmers. ${ }^{19}$ Day after 
day, he responded to questions from merchants and planters, all of whom were in some way entangled in the webs of credit, finance, and property that had by the late nineteenth century penetrated deep into the Omani interior through merchants like Ratansi and his middlemen. As the credit market in East Africa began to extend back into Oman at the time of the date trade, Al-Salimi was willing to furnish a legal framework that was supple enough to accommodate the range of transactions merchants and financiers engaged in. Through his turn-of-the-century fatwas (responses to legal questions brought before him) he helped merchants, planters, and other migrants moving between Oman and East Africa sort through a whole host of different sorts of obligations, the bulk of which involved one form of property or another. Omanis, it was clear from his fatwas, were highly engaged in trans-oceanic migration and trade.

As in the case of 'Abdullah, Salem, and Saif, the mobility of people, capital, and property across the Indian Ocean rested in part on a system of rights and obligations between principals and the agents (wakils) they appointed across the ocean. And people asked Al-Salimi many questions about their wakils, whether they were based in East Africa (which they often referred to using "Zanjibār," or Zanzibar, as a synecdoche) or Oman. ${ }^{20}$ Like 'Abdullah's heirs, Al-Salimi's correspondents seemed especially concerned about wakils tasked with selling property abroad (mostly in Oman, on behalf of principals in East Africa) who ended up taking the property for themselves, and the implications this might have for trans-oceanic property transactions. ${ }^{21}$

In one instance, a Zanzibar-based Omani wanted to sell his property in Nizwa through a wakil. After a series of missed opportunities with potential buyers, the wakil decided to purchase the property himself, and paid his principal (i.e., the seller) most — but not all —of the asking price. Years later, presumably after the value of the land increased along with Oman's date boom, the principal decided that he wanted to annul the sale and take back the property. He approached a qadi, who then wrote to Al-Salimi outlining what had happened and asking for advice on what the seller's rights were. In his response, Al-Salimi upheld both parties' right to cancel the sale, affirming, moreover, that it passed to their heirs even after they died. Because the sale had not been completed - the buyer hadn't paid the full price - the seller retained the right to annul it. Until then, he argued, the buyer had a right to retain the property's harvest, since he occupied the land legally. ${ }^{22}$ The jurist set out rights for both parties within the framework of a growing date trade: the original property owner had the right to reclaim his land, while the wakil-cum-purchaser was able to retain whatever profits he had made in the interim.

What Al-Salimi spent the most time dealing with, however, were issues surrounding property in death - the very sort that 'Abdullah's heirs were grappling with in the Zanzibar court at roughly the same time. When Omanis who moved between East Africa and South Arabia died, their heirs looked to Al-Salimi to help sort out the claims that heirs an ocean apart might have on the estates. For Al-Salimi, space was no deterrent to the rightful claims of an heir: in his response to a request for advice 
from the family of an Omani who had spent his years travelling between South Arabia and East Africa and died leaving families on both coasts, Al-Salimi contended that every heir had a right to the estate, and that he did not see "that distance or the sea was an obstacle to that." 23

But even if the ocean wasn't an obstacle to people's right to claim their inheritance, it could pose significant complications. The time it took to travel across the Western Indian Ocean and back left plenty of room for different actors to fashion their claims in ways that best suited their interests. In one case, the Zanzibar heirs to a property in Oman appointed a wakil to dispose of the estate and return with the money. Upon his return, one of the heirs denied having ever authorised him to sell his inheritance, and had in the meantime sold off his share to an interested buyer. ${ }^{24}$ Another case involved multiple wakils and just as many instructions for the execution of a will of property in Oman from Zanzibar. ${ }^{25}$ And in one particularly egregious case, an Omani husband to four wives spent his last days travelling around the East African coast, divorcing his Omani wives one by one as he married in East Africa. After his death, confusion lingered as to precisely which wives he divorced, and whether any one of them would have to withdraw her right to inherit from his estate. ${ }^{26}$

At times, death posed questions about what to do with property investments. One qadi relayed a story of an Omani who travelled to Zanzibar and took up residence there and, years later, invested in a plantation in Oman - one that he had never seen before. Because he lived in Zanzibar, the man appointed his daughter to look after the property's upkeep and shared the harvest with her; after some time, he decided to gift it to her. However, when he passed away, other heirs came forward to claim their share of the plantation; the daughter then produced the deed through which her father had gifted her the property, and brought witnesses to attest to her having managed it over the years. The qadi wanted to know whether her claim stood. AlSalimi upheld the daughter's right: as long as the deed was good, he argued, the claim stood on its own, and none of the heirs had the right to demand the gift's annulment. ${ }^{27}$

As greater numbers of Omanis travelled between South Arabia and East Africa, taking with them people and property, they and their qadis looked to jurists like Al-Salimi to help them sort through the broad range of contracts, promises, rights, and obligations they generated. In life or in death, Al-Salimi was their guide through the thickets of contracts, institutions, and law, and he was more than willing to draw on his legal knowledge in order to make their world more intelligible and navigable.

The questions Al-Salimi was asked were also all the more pressing now that international capital had made it into the date plantations by way of merchants like Ratansi Purshottam and others. Al-Salimi's correspondents made frequent mention of their Indian financiers and their lending activities. They wrote to him on at least a few different occasions to voice their concerns about their business relationships with their Indian financiers. One wrote to Al-Salimi explaining that in transactions with Hindu moneylenders (whom jurists referred to as al-bānyān - the banias), "you take money in the form of a loan or debt and you give him [your produce] to sell for you, 
and he takes a sales commission, and if you do not do that he does not give you money, and if you do the commission is lost to you, going to him and to others." The letter didn't involve a question, but Al-Salimi took it as an expression of moral qualms. He reassured his correspondent: "it is to you to take the loan, and his ill intentions and bad practices will not affect you." 28 Omani planters were not morally responsible for having to engage in unequal commercial relationships. And whatever he thought of the moneylenders themselves, Al-Salimi voiced few objections to the general sorts of property transfers taking place around him, channelling the creative energies of past jurists to provide his correspondents with guidance on questions of property and credit. ${ }^{29}$ Obligations between sellers and buyers - as well as lenders and borrowers - could also be passed down from one generation to another. ${ }^{30}$

Al-Salimi's fatwas touched on many of the issues brought up in the series of cases between the litigants in the Zanzibar court-debts, Indian creditors, land, inheritance, wakils, and more fundamentally, how to regulate transactions taking place an ocean away. He was one of many scholars around the Indian Ocean thinking about issues like these: jurists around Oman, Hadramawt, and East Africa spent the better part of the nineteenth and early twentieth century tackling these issues. ${ }^{31}$ And like Al-Amawi, his counterpart in Zanzibar, Al-Salimi also envisioned an expansive Islamic legal space in the Western Indian Ocean - and one whose outlines were being traced and retraced with every movement, debt, question, and fatwa. The two jurists, Al-Salimi and Al-Amawi, might never have met, but their writings and utterances make it clear that these were legal actors who engaged in parallel exchanges with one another in a world that was still in motion, and which would have very easily intersected with the jurisdictional prerogatives of British colonial courts in East Africawhich by 1910 were ensconced in an altogether different set of legal transformations.

\section{New Legal Imaginaries}

Neither Al-Salimi nor Al-Amawi let on that their vision of an expansive Islamic jurisdiction might have been a product of an intellectual transformation as much as it was a commercial one. Both were products of a particular moment in Western Indian Ocean history: a trans-regional rejuvenation in Islamic thought and Muslim writing that owed a great deal to developments that took place in Zanzibar. The 1880s and 1890s heralded the beginning of a new era - a renaissance (nahda) in Islamic thought. The nahda received a major boost with the advent of a printing press in Zanzibar that devoted itself to the production of treatises in Islamic law and theology and echoed into the courtrooms of British East Africa. The riches of the East African commercial boom of decades past, it is clear, made their way back into the world of law in more ways than one.

Of the works printed in Zanzibar, none would become as popular as Muhammad ibn Yusuf Ațfiyyish's Sharh Kitāb Al-Nīl, a fourteen-volume legal commentary that quickly established itself as the most authoritative exposition of Ibadhi fiqh. ${ }^{32}$ Like most other texts of the commentary genre, the Sharh took on the whole gamut of 
Islamic positive law, from ritual ('ibādāt) matters to more mundane transactions (mu'ämalat $)$, though it was written with a clarity and elegance that was uncommon in Muslim legal writing. As printed books, texts like Attiyyish's were far cheaper to produce than their manuscript counterparts and could be sent across the ocean or desert in bulk, particularly in the age of the steamship and railroad. ${ }^{33}$ Works of Ibadhi scholarship were now much more widely studied by scholars in the Ibadhi world, and North African texts were just as accessible in Oman and East Africa as Omani and Zanzibari texts were in the M'zab. ${ }^{34}$ Other texts, like the thirteenthcentury Shafi'i manual Minhāj Al-Tälibīn or the famous sixteenth-century commentary Tuhfat Al-Muhtāj fì Sharh Al-Minhāj, also circulated alongside them, and also gained currency as authoritative works in their schools of jurisprudence; scholars in Oman and East Africa frequently referred to both Ibadhi and Shafi'i texts.

The nahd a also played out in the courtroom, carrying important implications for the administration of justice, particularly in East Africa. As texts like Ațiyyish's Sharh became more readily available, qadis in British courtrooms in East Africa were expected to refer to them in their opinions, and British judges with training in Arabic often utilised them in court. Thus, when an English judge sat in a courtroom at the onset of the twentieth century and was able to look directly to Islamic legal texts to formulate his opinion, he drew on texts that were immediately available to him in print - manuals of jurisprudence that had already been pre-selected for publication because of their perceived authoritativeness. Their usage in East African courtrooms by local and imperial juridical officials alike underscored a process of canonisation that was already underway.

As Saleh bin Sulaiman took his claim against 'Abdullah bin Salam's heirs to the lower court in Zanzibar in 1910, he could hardly have known that he was tapping into a trans-regional Ibadhi intellectual renaissance, or that his dispute with 'Abdullah's heirs would cast into relief the trans-oceanic movement of texts and actors that characterised the moment. And yet it did: as Saleh's lawyers drew on Indian statute and case law to make claims about how to read the burned document that lay at the center of the dispute, the judge and the qadis in the lower court drew on the texts and ideas that came out of Zanzibar's printing press and the nahda it supported.

But at the same time, all of the actors in that courtroom acknowledged the existence of another circuit of legal thinking and claim-making - one that drew heavily on the same intellectual transformations that the Zanzibar court tapped into, but channelled them towards the establishment of a very different jurisdiction. And the record makes it clear that these were not two parallel circuits of law making, but ones that intersected at various levels. Jurists in Oman and East Africa drew on the same intellectual currents to regulate the same trans-regional world of commerce - one that swung between East Africa and Oman over the course of the nineteenth century. These gave rise to parallel (and sometimes overlapping) circuits of legal administration and discourse, but also raise the possibility of tangible connections. One jurist who travelled around East Africa, 'Abdulaziz bin 'Abdulghani Al-Amawi (unrelated to Tahir bin Abibaker), maintained a regular correspondence with jurists in Oman 
over the course of the late nineteenth century, in which thinkers on both sides of the Indian Ocean grappled with questions of law, commerce, and property. ${ }^{35}$ His son, Burhan, who enjoyed a lengthy career in the British courts in Zanzibar, carried on the tradition, exchanging letters with qadis and jurists from around Arabia. And considering their ability to tap into a broader world of legal thought that circulated between Arabia and Africa, it should probably come as no surprise that Al-Amawi's son Burhan was one of the three qadis who weighed in on the 'Abdullah bin Salam case. $^{36}$

\section{Conclusion}

That courtroom in 1910, then, sat at the intersection of multiple scales of legal imagination- "oceans" of law, rather than a singular ocean. When Al-Amawi made the statement he did, he was recognising that nested within a British colonial court in Zanzibar lay the possibility to imagine, to look across the water, beyond the confines of an imperial legal bureaucracy, and see the possibilities for a multilayered world of law. His vision was in the abstract: Al-Salimi's contention that neither "distance nor the sea" abrogated the rights of heirs was couched within a practical vision-one that actively sought to facilitate the circulation of people, goods, and obligations around the Indian Ocean. As the two looked out across the sea in each other's direction, they left us with a sense of the possibilities for thinking and writing about the Indian Ocean world as a legal arena, or an "ocean of law."

Law was central to how different commercial actors imagined their place in and navigated the changing tides of the Indian Ocean world. As a technology, law furnished the institutions and instruments necessary to organise commerce and settlement between Oman, India, and East Africa, and to facilitate access to the capital necessary to fuel economic activity. As a discourse, Muslim jurisprudence furnished the intellectual underpinnings of this world, providing a philosophy for the nature and shape of the commercial obligations that ran through it and the institutions that governed it. And as a modality of rule, law was essential to the process by which a range of actors, from the expected to the unexpected, negotiated, established, and contested jurisdiction over the commercial world. ${ }^{37}$

But to reimagine the Indian Ocean as an "ocean of law" is to do a different kind of work altogether. It is, at its core, to take seriously the legal imaginaries of actors around the region and the categories, discourses, and instruments they mobilised to realise their vision. Islamic law - the universal jurisdiction of the qadi-did not exist only in the abstract, nor only in the textbooks that circulated between Zanzibar, Oman, and Algeria. It existed in the space that the legal imagination of someone like Al-Amawi helped create, the lexicon of contracting that the fatwas of Al-Salimi helped give rise to, and the contracts and instruments that opened up possibilities for merchants, moneylenders, planters, and other migrants to engage in exchange around the Indian Ocean. This imaginative work on the part of qadis and jurists like Al-Amawi and Al-Salimi (and there are dozens, if not scores, like them) formed the 
stuff of law's oceanic tapestries - the threads that made the tapestry, the handloom that spun the yarn, and the visions that gave it coherence.

But this was an imagined ocean of law that went beyond the jurists that gave it shape. If I've managed to say anything at all in this article, it is that these discourses would have been empty without the commercial actors - the 'Abdullah bin Salams, the Saif bin Hamouds, the Ratansi Purshottams, and the tens of thousands like them-who traversed the ocean, loaned out money, fought for their livelihoods, and ultimately asked the difficult questions about what was possible in this shifting seascape. Their parallel encounters with this changing legal world-encounters that one can't tie together into a neat bundle - traced the contours of their multiple oceans of law. The hundred horizons of the Indian Ocean were as much a part of their imagined futures as they were the imagination of the jurists who furnished them with the legal framework to make sense of it all.

And then there's the imaginative work that falls to the historian, who takes a series of disconnected utterances, isolated texts, and dusty case files, and weaves them together into a story of law in the Indian Ocean. In moving between scales, shifting vantage points, and joining together hitherto separated discourses, we allow the possibility for seeing the multiple currents of legality unfold-as connections, as circulations, as parallel encounters, and as a singular case awash in flows of law. And throughout, micro-level actions and imaginaries form the stuff of the macro, while macro-level processes and discourses saturate all aspects of the micro, whether the actors themselves could imagine it or not.

\section{Archival Sources}

Mohammed bin Ahmed Al-Busa'idi Library, Seeb, Oman.

Zanzibar National Archives (ZNA)

Ratansi Purshottam Library, Mattrah, Oman (RPL)

\section{Works Cited}

'Abdulaziz bin 'Abdulghani Al-Amawi. As'ila wa Ajwiba min al-Shaykh 'Abdul-'Aziz bin 'Abdulghani Al-Amawi, Qādī Zinjibār [Questions and answers from the shaikh 'Abdul-'Aziz bin 'Abdulghani Al-Amawi, the qadi of Zanzibar], dated 13 Dhu Al-Qu'da 1299 [26 September 1882]. Mohammed bin Ahmed Al-Busa'idi Library, Seeb, Oman, Series 6, Manuscript 589.

Al-Salimi, 'Abdullah bin Humayd. Jawābāt Al-Imām Al-Sālimi, 2nd ed. 7 vols. Muscat, Oman: Ministry of Awqaf and Religious Affairs, 1999.

Alexander, Gilchrist C. Tanganyika Memories: A Judge in the Red Kanzu. London: Blackie and Sons, 1936.

Allen, Calvin H. "The Indian Merchant Community of Masqaț." Bulletin of the School of Oriental and African Studies, University of London 44:1 (1981): 39-53.

Allott, Antony. "The Development of the East African Legal Systems during the Colonial Period.” In D. A. Low and Alison Smith, eds., History of East Africa, vol. 3. Oxford, U.K.: Clarendon Press, 1976. 
Bennett, Norman R. Arab Versus European: Diplomacy and War in Nineteenth-Century East Central Africa. New York: Africana Publishing Company, 1986.

Bhacker, M. Reda. Trade and Empire in Muscat and Zanzibar: Roots of British Domination. London: Routledge, 1994.

Bishara, Fahad Ahmad. "Paper Routes: Inscribing Islamic Law Across the Nineteenth Century Indian Ocean." Law and History Review 32:4 (2014): 797-820.

- A Sea of Debt: Law and Economic Life in the Western Indian Ocean, 1780-1950. Cambridge: Cambridge University Press, 2017.

Bose, Sugata. A Hundred Horizons: The Indian Ocean in the Age of Global Empire. Cambridge, MA: Harvard University Press, 2006.

Boxberger, Linda. "Avoiding Ribā: Credit and Custodianship in Nineteenth and EarlyTwentieth Century Hadramawt." Islamic Law and Society 5:2 (1998): 196-213.

Cooper, Frederick. Plantation Slavery on the East Coast of Africa. New Haven, Conn: Yale University Press, 1977.

Green, Nile. Bombay Islam: The Religious Economy of the Western Indian Ocean, 1840-1915. New York: Cambridge University Press, 2011.

Hoffman, Valerie. The Essentials of Ibādi Islam. Syracuse, N.Y.: Syracuse University Press, 2012.

Hopper, Matthew S. "The Globalization of Dried Fruit: Transformations in the Eastern Arabian Economy, 1860s-1920s." In James Gelvin and Nile Green, eds., Global Muslims in the Age of Steam and Print. Berkeley: University of California Press, 2013.

Landen, Robert G. Oman Since 1856: Disruptive Modernization in a Traditional Arab Society. Princeton, N.J.: Princeton University Press, 1967.

Lorimer, J. G. The Gazetteer of the Persian Gulf, Oman and Central Arabia. 6 vols. Slough, U.K: Archive Editions, 1905, Reprinted 1987.

McDow, Thomas F. Buying Time: Debt and Mobility in the Western Indian Ocean. Athens, OH: Ohio University Press, 2018.

McMahon, Elisabeth. Slavery and Emancipation in Islamic East Africa: From Honor to Respectability. New York: Cambridge University Press, 2013.

Metcalf, Thomas. Imperial Connections: India in the Indian Ocean Arena, 1860-1920. Berkeley: University of California Press, 2008.

Sheriff, Abdul. Dhow Cultures of the Indian Ocean: Cosmopolitanism, Commerce, and Islam. London: Hurst \& Co., 2010.

- Slaves, Spices and Ivory in Zanzibar. Oxford: James Currey, 1987.

Stiles, Erin. An Islamic Court in Context: An Ethnographic Study of Judicial Reasoning. New York: Palgrave Macmillan, 2009.

Stockreiter, Elke. Islamic Law, Gender, and Social Change in Post-Abolition Zanzibar. New York: Cambridge University Press, 2015.

Tomlins, Christopher. Freedom Bound: Law, Labor, and Civic Identity in Colonizing English America, 1680-1865. New York: Cambridge University Press, 2010.

Wilkinson, John C. The Arabs and the Scramble for Africa. Sheffield, U.K: Equinox Publishing, 2015.

—. The Imamate Tradition of Oman. New York: Cambridge University Press, 1987.

\section{Notes}

* Fahad Ahmad Bishara is assistant professor of history at the University of Virginia. He is the author of $A$ Sea of Debt: Law and Economic Life in the

Western Indian Ocean, 1780-1950 (Cambridge University Press, 2017). His research and writing explores the 
economic and legal history of the Indian Ocean and Islamic world.

1 Bose, A Hundred Horizons, 6-7. On the Indian Ocean as a "cultural continuum," see Sheriff, Dhow Cultures, 240, 263-97.

2 I use the term "mortgage" here as shorthand, to describe a rich form of contracting that actors referred to as "khiyār sales"property sales transactions that allowed for the seller to redeem the property after repaying the purchase price. For more detail on this form of contracting, see Bishara, "Paper Routes."

3 Petition by Saleh bin Sulaiman, Zanzibar National Archives (ZNA) HC 5/14 $\mathrm{A}$ and $\mathrm{B}$.

4 Magistrate Court Judgement, ZNA HC 5/14 A and B.

5 Seif bin Hamoud vs Mohamed bin Abdullah and Others (1923) 2 Zanzibar Law Reports 22.

6 Opinion of Shaikh Tahir bin Abibaker Al-Amawi (not dated), ZNA HC 5/14 $\mathrm{A}$ and $\mathrm{B}$.

7 See also Stockreiter, Islamic Law, Gender, and Social Change; Metcalf, Imperial Connections, 16-45; Alexander, Tanganyika Memories; Allott, "Development of the East African Legal Systems."

8 See also Stockreiter, Islamic Law, Gender, and Social Change; McMahon, Slavery and Emancipation; Stiles, An Islamic Court in Context.

9 An exception to this trend is Hopper, "The Globalization of Dried Fruit," and more recently, Thomas F. McDow, Buying Time: Debt and Mobility in the Western Indian Ocean (Athens, $\mathrm{OH}$ : Ohio University Press, 2018).

10 See also Sheriff, Slaves, Spices, and Ivory; Bhacker, Trade and Empire; Cooper, Plantation Slavery.

11 Landen, Oman Since 1856. A notable exception to this is Wilkinson's The Imamate Tradition of Oman.

12 Wilkinson, The Arabs and the Scramble for Africa; Bennett, Arab Versus European, 245-53.

13 Hopper, "Globalization of Dried Fruit," 161.
14 For the sake of consistency, I have converted these figures from British pounds to US dollars; in Lorimer, these figures are $£ 52,000, £ 92,500$, and $£ 103,000$ respectively. Lorimer, Gazetteer 1: 2307.

15 Hopper, "Globalization of Dried Fruit," 164-5.

16 The best account of Ratansi Purshottam's life, within the context of the history of the Indian merchant community of Muscat, is Allen, "The Indian Merchant Community of Masqat," 46-7.

17 There were small numbers of Indian merchants along Eastern Arabia who dealt in dates. Lorimer, Gazetteer 3: 965, 2297.

18 William Hills Jr. to Ratansi Purshottam (13 June 1906), Ratansi Purshottam Library (RPL), William Hills Documents, 3-4.

19 Al-Salimi was the premier jurist in late nineteenth-century Oman. However, he was not the only one writing at the time; other jurists also penned fatwas on various commercial issues, and Al-Salimi's legal opinions exhibit a clear debt to the writings of Omani jurists from earlier in the century; he was thus part of a broader group of Muslim scholars that helped guide Oman and East Africa's transformations during the nineteenth and early twentieth centuries, but was certainly the most prolific among them. See Wilkinson, The Imamate Tradition of Oman.

20 Al-Salimi, Jawābāt al-Imām al-Sālim̄̄ 4: 537-40, 543-4.

21 Ibid. 550-1.

22 Ibid. 310-1.

23 Ibid. 58-60.

24 Ibid. 49-50.

25 Ibid. 127-8.

26 Ibid. 192-3.

27 Ibid. 476-7.

28 Ibid. 439.

29 Bishara, "Paper Routes."

30 Ibid. 229, 268.

31 See also Boxberger, "Avoiding Ribä"; Bishara, A Sea of Debt. 
32 Atfiyyish, who kept a correspondence with Al-Salimi, was one of the principal Muslim scholars and reformers of the M'zab Valley in Algeria. His Sharh was a commentary on 'Abdul-'Aziz Al-Thamini's Kitāb Al-Nīl wa Shif à' al-'Alīl, considered a touchstone text in Ibadi fiqh. See Hoffman, Essentials of Ibādi Islam, 24.

33 See also Green, Bombay Islam, 92-9.
34 Wilkinson, The Imamate Tradition of Oman, 243.

35 'Al-Amawi, As'ila wa Ajwiba.

36 "Wathā'iq Tārīkhiyya min Zinjibār [Historical documents from Zanzibar]" n.d. Mohammed bin Ahmed Al-Busa'idi Library.

37 This is an adaptation of ideas in Tomlins' Freedom Bound, 5-6. 